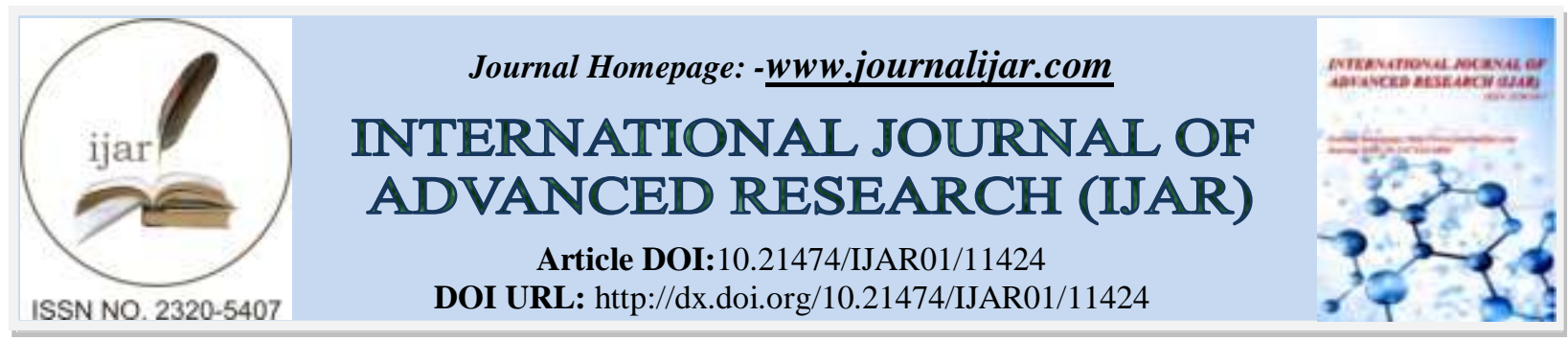

RESEARCH ARTICLE

\title{
GC-MS PROFILE, ANTIBACTERIAL, ANTIFUNGAL, AND ANTICANCER ACTIVITY OF ROOT OF VANDA TESSELLATA AN EPIPHYTIC ORCHID
}

\author{
Nunna Venkata Ramana ${ }^{1}$, P.K Ratna Kumar ${ }^{2}$ and Bandaru Venkateswara Rao ${ }^{3}$ \\ 1. Department of Botany, KRK Government Degree College, Addanki, Prakasam (Dist). \\ 2. Department of Botany, Andhra University, Vishakhapatnam. \\ 3. Department of Botany, Andhra University, Vishakhapatnam.
}

\section{Manuscript Info}

Manuscript History

Received: 28 May 2020

Final Accepted: 30 June 2020

Published: July 2020

Key words:-

Epiphytes, Orchidaceae, Antimicrobial Activity, Ethyl Acetate, Disc Diffusion Method, Dilution Technique, SAB Assay, GC-MS Analysis

\begin{abstract}
Background:The presence of phytochemical constituents has been reported from species of the Orchidaceae. Hitherto no reports exist on the GC-MS Profile of Vanda tessellata Hook. Ex G. Don which was an epiphyte from the sacred groove of Penchalikona of Andhra Pradesh.

Objective:The current study was to determine the antibacterial, antifungal,anticancer activities, and GC-MS profiles of the root of Vanda tessellata Hook. Ex G. Don.

Materials and Methods:The root of the Vanda tessellata Hook. Ex G. Don which was an epiphytic orchid from the sacred groove of Penchalikona of Andhra Pradesh.

An in-vitro evaluation of antibacterial and antifungal activity was performed by disc diffusion method and dilution technique, and anticancer activity was performed by $\mathrm{SAB}$ assay.

Gas chromatography-mass spectrometry (GC-MS) analysis of the root extracts of Vanda tessellata Hook. Ex G. Don was performed on GCMS equipment (GCMSQP2010, SHIMADZU).

Results:The GC-MS profile has shown the presence of different phytochemical compounds in the epiphytic root of Vanda tessellata Hook. Ex G. Don. A total of 33 compounds were identified. Furthermore, the results of antibacterial and antifungal tests (both primary and secondary) shown that substantial antibiotic activity, and the anticancer activity results are shown inactivity.

Conclusion:From the results, it is evident that epiphytic root extracts of Vanda tessellata Hook. Ex G. Don has shown substantial antibacterial, and antifungal activity and GC-MS profile revealed the 33 analytes confirming the root was a source of therapeutic compounds useful for the pharmaceutical applications.
\end{abstract}

Copy Right, IJAR, 2020, All rights reserved.

\section{Introduction:-}

Epiphytes are extreme specialists adapted various morphological and physiological characters for their survival. Scientists summarised some important applications of orchids in controlling fevers, curing eye diseases, treating fatigue, headaches and their function as anticancer agents [15].Orchidaceae is the second-largest angiosperm family in India, consisting of about 990 Genera. Nine species of orchids used for medicine in south India [25]. 


\section{Materials and Methods:-}

This species was collected from the Penchalikona area. Penchalikona is located in Sri Potti Sri Ramulu district of Andhra Pradesh (Latitude 14" 18" N, Longitude 70"28") $3000 \mathrm{ft}(900 \mathrm{~m})$ above sea level. It is an epiphytic herb,belongs to the family Orchidaceae. (Fig-1)

Table-1:- Plant species and medicinal uses

\begin{tabular}{|l|l|l|l|l|}
\hline S.NO & $\begin{array}{l}\text { Place of } \\
\text { Collection }\end{array}$ & Scientific name & Part & Uses \\
\hline 1 & Penchalikona & Vanda tessellata & Roots & $\begin{array}{l}\text { Treat bronchitis, inflammation, } \\
\text { hiccup, piles and boils on the scalp }\end{array}$ \\
\hline
\end{tabular}

\section{Description of plant species:}

Habit:

Herb

\section{Habitat:}

Dry and moist deciduous forests and also in the plainsand on foothills to about $750 \mathrm{~m}$, on slopes, sometimes in dense masses on decaying trees. Flower, Fruit: March-October

\section{Morphology:}

An epiphytic orchid, with stem 30-60 cm in height, thick, scandent with branching aerial roots. Its leaves $15-20 \mathrm{~cm}$ thick, fleshy, long, linear, recurved and complicate. Flowers in 6-10 flowered racemes, reaching with the peduncle $15-25 \mathrm{~cm}$ long. Its sepals are yellow, tessellated with brown lines and with white margins and petals are yellow with brown lines and white margins, shorter than the sepals. Lip is $16 \mathrm{~mm}$ long, bluish, with purple dots. Capsules are $7.5-9 \mathrm{~cm}$ long, narrowly clavate- elongated with acute ribs.
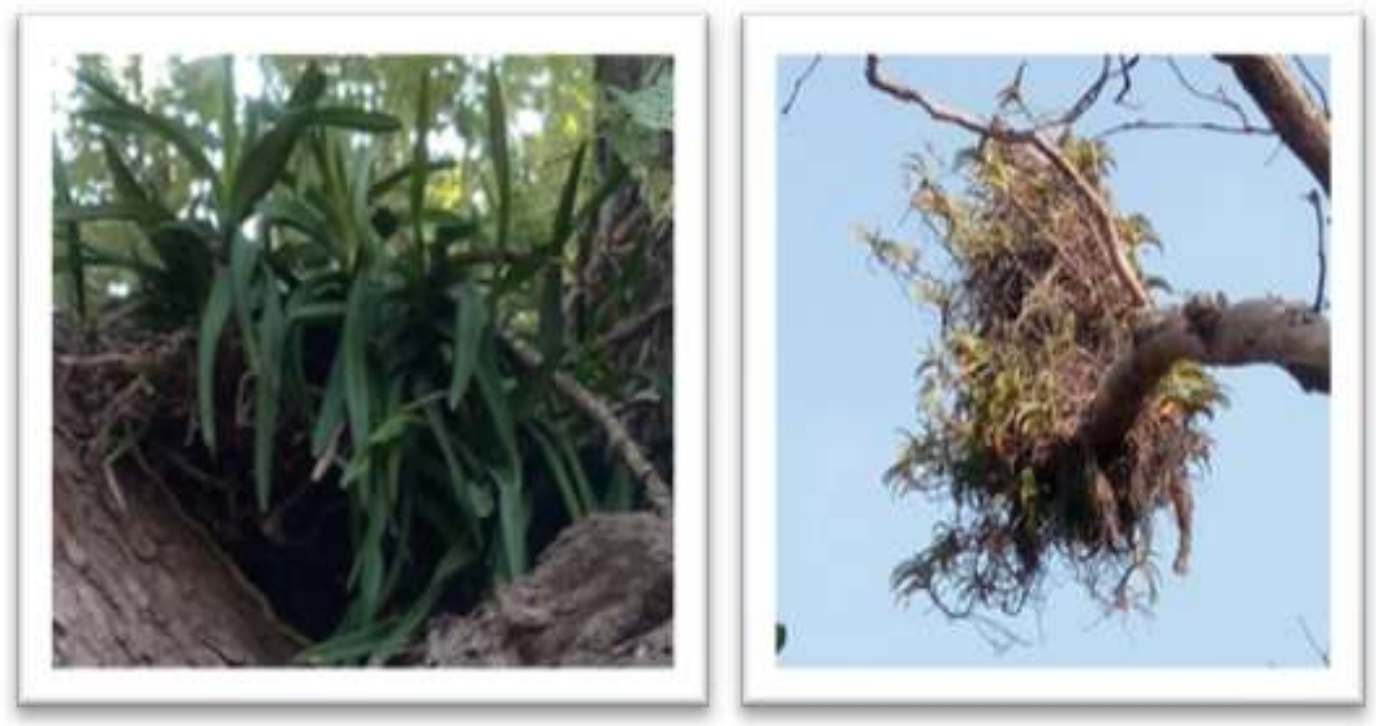

Fig-1:- Vanda tessellate.

\section{Plant Identification:}

Herbarium specimens are prepared and identified by B.S.I of Hyderabad. Herbarium of the plant was preserved in the Department of Botany, Andhra University, Vishakhapatnam.

\section{Preparation of plant extracts:}

The roots were separated, and surface sterilized with $0.1 \% \mathrm{Hg} \mathrm{Cl} 2$ for 5 minutes washed thrice with sterilized distilled water 5 minute each time. They were shade dried for forty days and powdered. Powder of the test material was dissolved in three different solvents viz methanol, ethyl acetate, and n-hexane for in vitro antimicrobial studies. 


\section{Antibacterial activity:}

Antibacterial activity of different extracts of the test species was conducted in two phases, i.e., i) Antibacterial activity (disc-diffusion method) ii) Antibacterial activity (MIC) (dilution method).

\section{Disc diffusion method [19]}

\section{Principle:}

Agar disk-diffusion testing method provides a simple and effective test in antimicrobial studies to measure the effect and sensitivity of a particular substance on a specific bacterium. In this method, agar plates are inoculated with standardized inoculums of the test microorganism. Then, filter paper discs (about $6 \mathrm{~mm}$ in diameter), containing the test compound at the desired concentration, are placed on the agar surface. The Petri dishes are incubated under suitable conditions. The substance diffuses into the agar and inhibits the growth of the test microorganism. The degree of susceptibility is determined by measuring the diameters of inhibition zone due to diffusion of the test compound from the disc into the surrounding medium.

\section{Preparation of the antibiotic disc with root extracts:}

A stock solution of extract was prepared with the dried powdered plant materials by hot extraction process by using a Soxhlet extraction device with respective solvents viz. methanol, ethyl acetate and n-hexane (1:1). The stock solution was then diluted with different concentrations. $0.2 \mathrm{ml}$ of each dilution was impregnated into sterile, blank discs (Whatman N0.1 filter paper) $6 \mathrm{~mm}$ in diameter. All discs were fully dried.

\section{Procedure:}

Agar plateswith Mueller Hinton Agar (MHA) are seeded with the test bacterium strain and labelled. Leave culture Plate for 5-10 min at room temperature by closing the culture plate. Place the impregnated disc at the centre of plate using disc dispensers. Gently press antibiotic paper disc by forceps so that there is no gap left between the disc and bacterial culture. Incubate plates at $37^{\circ} \mathrm{C}$ for 24 hours. After 24 hours, the inhibition diameter around each disc was measured and recorded. Each extract was tested in triplicate. Negative control was prepared with only methanol extract used for extraction.

\section{Minimal inhibition concentration (MIC): \\ Dilution technique[19]: \\ Principle:}

Dilution method is the primary method of determination of MIC values. Agar dilution method used to quantitatively measure the In vitro antimicrobial activity against bacteria and fungi.MIC value recorded is the lowest concentration of the assayed antimicrobial agent that inhibits the visible growth of the tested microorganism and expresses in $\mu \mathrm{g} / \mathrm{ml}[20]$.

\section{Procedure:}

The secondary antibacterial activity of the root extracts was carried out using the dilution technique, and minimum inhibitory concentration (MIC) was determined [19]. Root extracts were dissolved in different solvents with different concentrations was tested for antibacterial activity.

Actively growing selected bacterial strains were respectively spread on nutrient agar plates and wells were made using sterile agar borer. Different aliquots $(100 \mu \mathrm{g} / \mathrm{ml}, 75 \mu \mathrm{g} / \mathrm{ml}, 50 \mu \mathrm{g} / \mathrm{ml}, 25 \mu \mathrm{g} / \mathrm{ml})$ of root extracts were added in separate wells and incubated at $28^{\circ} \mathrm{C}-30^{\circ} \mathrm{C}$ and incubated for $24 \mathrm{~h}$. After incubation measure the radius of the zone of inhibition.

\section{Antifungal activity:}

Antifungal activity of different extracts of the test species was conducted in two phases. i)Antifungal activity (discdiffusion method) ii) Antifungal activity (MIC) (dilution method).

\section{Antifungal activity:}

Inoculums of three fungal strains were selected in the present study viz., Fusarium oxysporium, Phytophthora infestans, Sclerotium rolfsii were obtained from Department of Biotechnology, Mahatma Gandhi University, Nalgonda, Telangana, India. Antifungal activity was tested employing a disc diffusion method [20]. 


\section{Disc diffusion method: Media preparation:}

Dissolve $24 \mathrm{gm}$ of PDB in $1000 \mathrm{ml}$ water to obtain PDB-Potato Dextrose Broth for fungal growth.The broth was sterilized by autoclaving at $121^{\circ} \mathrm{C}$ and $15 \mathrm{lb}$. Pressure for fifteen minutes. The sterilized medium $(20 \mathrm{ml})$ was poured in sterilized Petri dishes under aseptic conditions, allowing them to solidify on a plane table.

\section{Procedure:}

Inoculation of fungal strains in autoclaved PDB media and Incubate 3-4 days at $30^{\circ} \mathrm{C}$ in a shaker for fungal growth. From that $20 \mu$ l of fungal culture was taken and inoculated by inoculation loop on freshly prepared autoclaved agar plates. Filter paper discs (Whatman N0.1 filter paper) of about $6 \mathrm{~mm}$ in diameter impregnated withthe test compound at the desired concentration, are placed on the agar surface on the fungal plate. The incubation of the plates was done for 2 to 4 days at $30^{\circ} \mathrm{C}$ in the BOD incubator. Zone of inhibition around each disc was measured by measuring scale and recorded. Negative control was prepared with only methanol extract used for extraction.

The inhibition percentage (I \%) was calculated using the formula.

$\mathrm{I} \%=(\mathrm{C}-\mathrm{T}) * 100 / \mathrm{C}$

Where I = Inhibition \% of mycelial growth (growth reduction over control), $\mathrm{C}=$ Radial growth of the fungus in the control plate $(\mathrm{mm})$,

$\mathrm{T}=$ Radial growth of fungus on the inoculated plate.

\section{Minimal Inhibition concentration (MIC):}

An agar plugs of actively growing fungal culture was placed in the center of the PDA plates, respectively. Plates were incubated for $24 \mathrm{~h}$ then, wells were made using sterile agar borer $2 \mathrm{~cm}$ away from the center where fungal was placed, and different aliquots $(100 \mu \mathrm{g} / \mathrm{ml}, 75 \mu \mathrm{g} / \mathrm{ml}, 50 \mu \mathrm{g} / \mathrm{ml}, 25 \mu \mathrm{g} / \mathrm{ml})$ of root extracts were added in separate wells and incubated at $28^{\circ} \mathrm{C}-30^{\circ} \mathrm{C}$ and incubated for $24 \mathrm{~h}-96 \mathrm{~h}$. The inhibition percentage (I \%) was calculated using the formula $\%=(\mathrm{C}-\mathrm{T}) * 100 / \mathrm{C}$

WhereI $=$ Inhibition \% of mycelial growth (growth reduction over control),

$\mathrm{C}=$ Radial growth of the fungus in the control plate $(\mathrm{mm})$,

$\mathrm{T}=$ Radial growth of fungus on the inoculated plate.

\section{Anticancer activity:}

SRB assay:

Principle:

SRB assay is developed in the year 1990. After its development, the SRB assay used to conduct various screening assays to investigate cytotoxicity in cell-based studies[34].This method mainly relies on the property of SRB, which binds stoichiometrically to proteins under mildly acidic conditions and it can be extracted using alkaline conditions, the amount of bound dye considered for proxy for cell mass which can be extrapolated to measure cell proliferation.

\section{Experimental Procedure:}

\section{Preparation of treatment:}

In the present study, the cell lines (Human Hepatoma Cell Line Hep-G2, Murine Skin Melanoma Cell Line B16F10) were grown in RPMI 1640 medium containing 10\% fetal bovine serum and $2 \mathrm{~mm}$ L-glutamine. Depending on the doubling time of individual cell lines cells were inoculated into 96 well microtiter plates in $100 \mu \mathrm{L}$ at plating densities depending on the doubling time of individual cell lines for the present screening experiments.

\section{Incubation of cells:}

After the cell inoculation completed, microtiter plates were incubated at conditions $37^{\circ} \mathrm{C}, 5$ per cent $\mathrm{CO}_{2}, 95$ per cent air and 100 per cent relative humidity for $24 \mathrm{~h}$ before the addition of experimental drugs.

\section{Cell fixation and SRB staining:}

roots powder was initially solubilized in dimethyl sulfoxide (DMSO) at $100 \mathrm{mg} / \mathrm{ml}$ and using water diluted to $1 \mathrm{mg} / \mathrm{ml}$ and stored frozen before use. An aliquote of frozen concentrate $(1 \mathrm{mg} / \mathrm{ml})$ was melted and a dilute solution of $100 \mu \mathrm{g} / \mathrm{ml}, 200 \mu \mathrm{g} / \mathrm{ml}, 400 \mu \mathrm{g} / \mathrm{ml}$ and $800 \mu \mathrm{g} / \mathrm{ml}$ prepared with complete medium containing test article before the time of drug addition. Already appropriate microtiter plates containing $90 \mu \mathrm{l}$ of the medium are present. For 
these aliquots of $10 \mu \mathrm{l}$ of this different drug,dilutions were added resulting in the required final drug concentrations,i.e., $10 \mu \mathrm{g} / \mathrm{ml}, 20 \mu \mathrm{g} / \mathrm{ml}, 40 \mu \mathrm{g} / \mathrm{ml}, 80 \mu \mathrm{g} / \mathrm{ml}$. After that compound is added to the plates and Plates were incubated at standard conditions for 48 hours, after that by the addition of cold TCA and the assay was terminated. After that gentle addition of $50 \mu \mathrm{l}$ of cold $30 \%(\mathrm{w} / \mathrm{v})$ TCA (final concentration, $10 \%$ TCA) the in-situ fixation of the cells took place and incubated for sixty minutes at $4^{\circ} \mathrm{C}$. Discarded the supernatant after the experiment, the plates were washed five times with tap water and air-dried. For each ofthe wells Sulforhodamine B $(\mathrm{SRB})$ solution $(50 \mu \mathrm{l})$ at $0.4 \%(\mathrm{w} / \mathrm{v})$ in $1 \%$ acetic acid was and plates were incubated for 20 minutes at room temperature conditions. The unbound dye was recovered after staining, and the residual dye was removed by washing five times with $1 \%$ acetic acid. The plates were air-dried. With a $10 \mathrm{~mm}$ trizma base, the bound stain was subsequently eluted. By using a plate reader and the absorbance was read at a $540 \mathrm{~nm}$ wavelength using a reference wavelength of $690 \mathrm{~nm}$. On a plate-by-plate basis for test wells, per cent growth was calculated by comparing with control wells. The ratio of average absorbance of the test well to the average absorbance of the control well*100 is called growth percentage.

\section{Absorbance measurement:}

Mainly six absorbance measurements (time zero (Tz), control growth $(\mathrm{C})$ and test growth in the presence of drug at four concentration levels (Ti)are taken into account for the calculation of percentage growth at each concentration level. Growth inhibition percentage was calculated as $\mathbf{T i} / \mathbf{C} * \mathbf{1 0 0}$.

\section{GC-MS Analytical technique: \\ Principle:}

GC-MS is a combination of two different analytical techniques, Gas Chromatography (GC) and Mass Spectrometry (MS), which analyse complex biochemical and organic mixtures [28]. The two main components of the GC-MS instrument are the gas chromatography portion and a mobile phase. The gas chromatography portion which splits dissimilar compounds in the sample into pulses of pure substances based on their instability [22] by flowing inert gas (mobile phase), which moves the sample, across a stationary phase fixed in the column [28]. Spectra of compounds are gathered as they are leaving a chromatographic column by the mass spectrometer, which recognizes and counts the chemicals according to the mass-to-charge ratio $(\mathrm{m} / \mathrm{z})$. These generated spectra can then be stored on the computer and analysed [22].

\section{Methodology:-}

Gas Chromatography-Mass Spectrum Analysis (GC-MS) GC-MS technique was used in this study to identify the phyto components present in the root extracts. The GC-MS analysis of this extract was performed using GC SHIMADZU QP2010 system and gas chromatograph interfaced with a Mass Spectrometer (GC-MS) equipped with Elite-1 fused silica capillary column (Length: 30.0m, Diameter: $0.25 \mathrm{~mm}$, Film thickness: $0.25 \mu \mathrm{m}$ Composed of $100 \%$ Dimethylpolysiloxane). For GC-MS detection, an electron ionization energy system with ionization energy of $70 \mathrm{eV}$ was used. For each sample, the lyophilized compounds were dissolved in 5011 pyridine (Sigma-Aldrich, Steinheim, Germany), sonicated, and then derivatized in $60 \mathrm{ll}$ bis (trimethylsilyl)-trifluoroacetamide (SigmaAldrich) at $75 \circ \mathrm{C}$ for $45 \mathrm{~min}$.

GC-MS analysis was accomplished on a Shimadzu QP 2010 GC-MS system using a $30 \mathrm{~m} \times 0.25 \mathrm{~mm}($ i.d.) $\times 0.25$ $1 \mathrm{~m}$ DB5-MS fused-silica capillary column ( $\&$ W Scientific, Folsom, CA).The temperature injector was $280^{\circ} \mathrm{C}$, and the split ratio was 10: 1 . The carrier gas (Helium) is with a linear velocity of $35.0 \mathrm{~cm} \mathrm{~s}-1$ and an equilibration time of 3 minutes. The temperature of the column keeps at $70^{\circ} \mathrm{C}$ at the beginning for $5 \mathrm{~min}$ and then increased to $280^{\circ} \mathrm{C}$ at $5^{\circ} \mathrm{C}$ min 1 , held for $5 \mathrm{~min}$. The MS scan parameters included a mass scan range of $\mathrm{m} / \mathrm{z} 40-600$, a scan-interval of $0.5 \mathrm{~s}$, a scan speed of $1000 \mathrm{u} \mathrm{s}-1$, and a detector voltage of $0.9 \mathrm{kV}$. The ion source temperature was fixed to $200^{0} \mathrm{C}$, and the interface temperature was $280^{\circ} \mathrm{C}$. The solvent cut time was $6 \mathrm{~min}$.

The carrier gas such as Helium was used at a constant flow rate of $1.51 \mathrm{ml} / \mathrm{minutes}$, and a volume of injection $2 \mu \mathrm{l}$ was used. Injector temperature was $200^{\circ} \mathrm{C}$, and Ion-source temperature was $200^{\circ} \mathrm{C}$. The programming of oven temperature was at $70^{\circ} \mathrm{C}$ (isothermal for two min.), with an increase of $300^{\circ} \mathrm{C}$ for 10 min. Mass spectra were noted at $70 \mathrm{eV}$; a scan-interval of 0.5 seconds with a scan range of $40-1000 \mathrm{~m} / \mathrm{z}$. Total GC running time was $35 \mathrm{~min}$. After the comparison of its average peak area to the total areas, the relative percentage amount of each component was calculated Software adapted to handle mass spectra, and chromatograms was a GC MS solution ver. 2.5. 


\section{Results:-}

Antibacterial activity:

Antibacterial activity of different root extracts was conducted in two phases. Preliminary studies were carried out by disk diffusion method to find out the susceptibility of selected bacterial strains to each of the tested root extracts. Based on the primary activity of the tested extracts on the bacterial strains, selected root extracts were tested on the bacterial isolates to determine the minimum inhibitory concentration (MIC) to find out the effectiveness. The lowest concentration of the tested root extracts that inhibits the visible growth of the microorganism tested, recorded as MIC value and is expressed as $\mu \mathrm{g} / \mathrm{ml}$ or $\mathrm{mg} / \mathrm{L}$.

Root extracts of Vanda tessellata, evaluated in three different solvents viz., methanol, n-hexane and ethyl acetate against two gram-positive bacteria Staphylococcus aureus (MTCC - 96), Bacillus subtilis and two gram-negative bacteria Escherichia coli (MTCC - 443), Pseudomonas aeruginosa (MTCC - 424) by disk diffusion method.

Methanolic root extracts of $V$. tessellata were effective against gram-negative bacteria E. coli and $P$. aeruginosa. (Table-2 \&Fig-2)

Table 2:- Analysis of the preliminary antibacterial activity of different root extracts.

\begin{tabular}{|l|l|l|l|}
\hline Plant species & \multicolumn{2}{|l|}{ Vanda tessellata } \\
\hline Bacterial species & Zone of Inhibition(mm) & EA \\
\cline { 2 - 4 } & ME & NH & 5 \\
\hline Bacillus subtilis & $* *$ & $* *$ & 5 \\
\hline Staphylococcus aureus & $* *$ & $* *$ & 5 \\
\hline Pseudomonas aerungiosa & 5 & $* *$ & 7 \\
\hline Escherichia coli & 6 & $* *$ & \\
\hline
\end{tabular}

$\mathrm{ME}=$ Methanolic extract, $\mathrm{NH}=\mathrm{N}-\mathrm{Hexane}$ extract, $\mathrm{EA}=$ Ethyl acetate extract $* *=$ No activity

Ethyl acetate root extracts of $V$. tessellata were most effective on all the four bacterial strains tested. (Table-2 \&Fig-2)

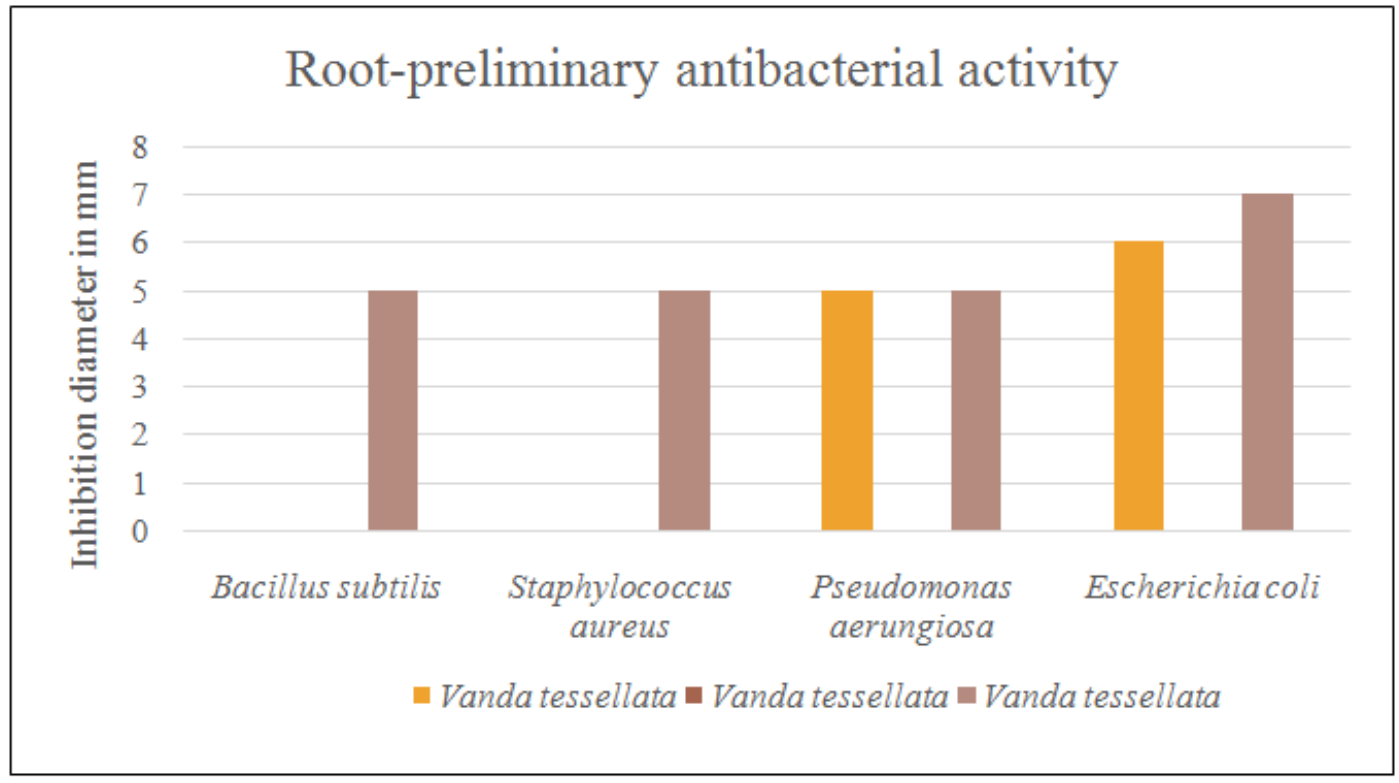

Fig 2:- Analysis of preliminary antibacterial activity of different root extracts.

None of the n-hexane root extracts of $V$. tessellata has shown any inhibitory activity on the bacterial strains tested. Minimum inhibitory concentrations (MIC's) of the effective root's extracts:

Basing on the results obtained minimum inhibitory concentrations (MIC's) of the effective root extracts were employed to study their bacteriostatic properties. 
Methanolic root extracts of $V$. tessellata induced inhibitory activity against $B$. subtilis, E. coli and $S$. aureus, and exerted the highest inhibition on the gram-negative $P$. aeruginosa at three lower doses. (Table:3 \&Fig:3\&Plate-1)

Table3:-Antibacterial activity (MIC) comparative analysis of root extracts

\begin{tabular}{|c|c|c|c|c|c|c|c|c|c|c|c|c|c|c|c|c|c|}
\hline & & B. $s u$ & tilis & & & S. au & eus & & & P. $a e$ & ugino & & & $\overline{E . c}$ & & & \\
\hline$\ddot{\Xi}$ & & Zon & of inh & bitio & mm) & Zon & of inh & bitiol & mm) & Zon & of inh & bition & mm) & Zol & of in & bitlon & m) \\
\hline$\frac{\sigma}{a}$ & $\bar{\delta} \Xi$ & 25 & 50 & 75 & 100 & 25 & 50 & 75 & 100 & 25 & 50 & 75 & 100 & 25 & 50 & 75 & 100 \\
\hline V.tessellata & ME & $\begin{array}{l}2 \\
\pm 0.05 \\
\end{array}$ & $\begin{array}{l}2 \\
\pm 0.05 \\
\end{array}$ & $\begin{array}{l}2.5 \\
\pm 0.02 \\
\end{array}$ & $* *$ & $\begin{array}{l}2 \\
\pm 0.05 \\
\end{array}$ & $\begin{array}{l}4 \\
\pm 0.05 \\
\end{array}$ & $\begin{array}{l}3 \\
\pm 0.05 \\
\end{array}$ & $\begin{array}{l}3 \\
\pm 0.05\end{array}$ & $\begin{array}{l}5 \\
\pm 0.05\end{array}$ & $\begin{array}{l}4 \\
\pm 0.05\end{array}$ & $\begin{array}{l}4 \\
\pm 0.05\end{array}$ & $* *$ & $\begin{array}{l}2 \\
\pm 0.05\end{array}$ & $\begin{array}{l}3.5 \\
\pm 0.02\end{array}$ & $\begin{array}{l}3 \\
\pm 0.05\end{array}$ & $\begin{array}{l}3 \\
\pm 0.05\end{array}$ \\
\hline & EA & $\begin{array}{l}2 \\
\pm 0.05\end{array}$ & $\begin{array}{l}2.5 \\
\pm 0.02\end{array}$ & $\begin{array}{l}3 \\
\pm 0.05\end{array}$ & $\begin{array}{l}5 \\
\pm 0.05\end{array}$ & $\begin{array}{l}3 \\
\pm 0.05\end{array}$ & $\begin{array}{l}3.5 \\
\pm 0.02 \\
\end{array}$ & $\begin{array}{l}3 \\
\pm 0.05\end{array}$ & $\begin{array}{l}3.5 \\
\pm 0.02\end{array}$ & $\begin{array}{l}2.5 \\
\pm 0.02 \\
\end{array}$ & $\begin{array}{l}2.5 \\
\pm 0.02 \\
\end{array}$ & $\begin{array}{l}2.5 \\
\pm 0.02 \\
\end{array}$ & $\begin{array}{l}3 \\
\pm 0.05\end{array}$ & $* *$ & $\begin{array}{l}2 \\
\pm 0.05\end{array}$ & $\begin{array}{l}2 \\
\pm 0.05\end{array}$ & $\begin{array}{l}2 \\
\pm 0.05\end{array}$ \\
\hline
\end{tabular}

Concentrations $(\mu \mathrm{g} / \mathrm{ml})$ 25,50,75,100 ME=Methanolic extract; EA= Ethyl acetate extract; \pm standard mean error; $* *=$ No activity

Ethyl acetate root extracts of. $V$. tessellata exerted inhibitory activity on both gram + and gram- bacterial isolates at all concentrations. (Table-3\&Fig-3\&Plate-1)

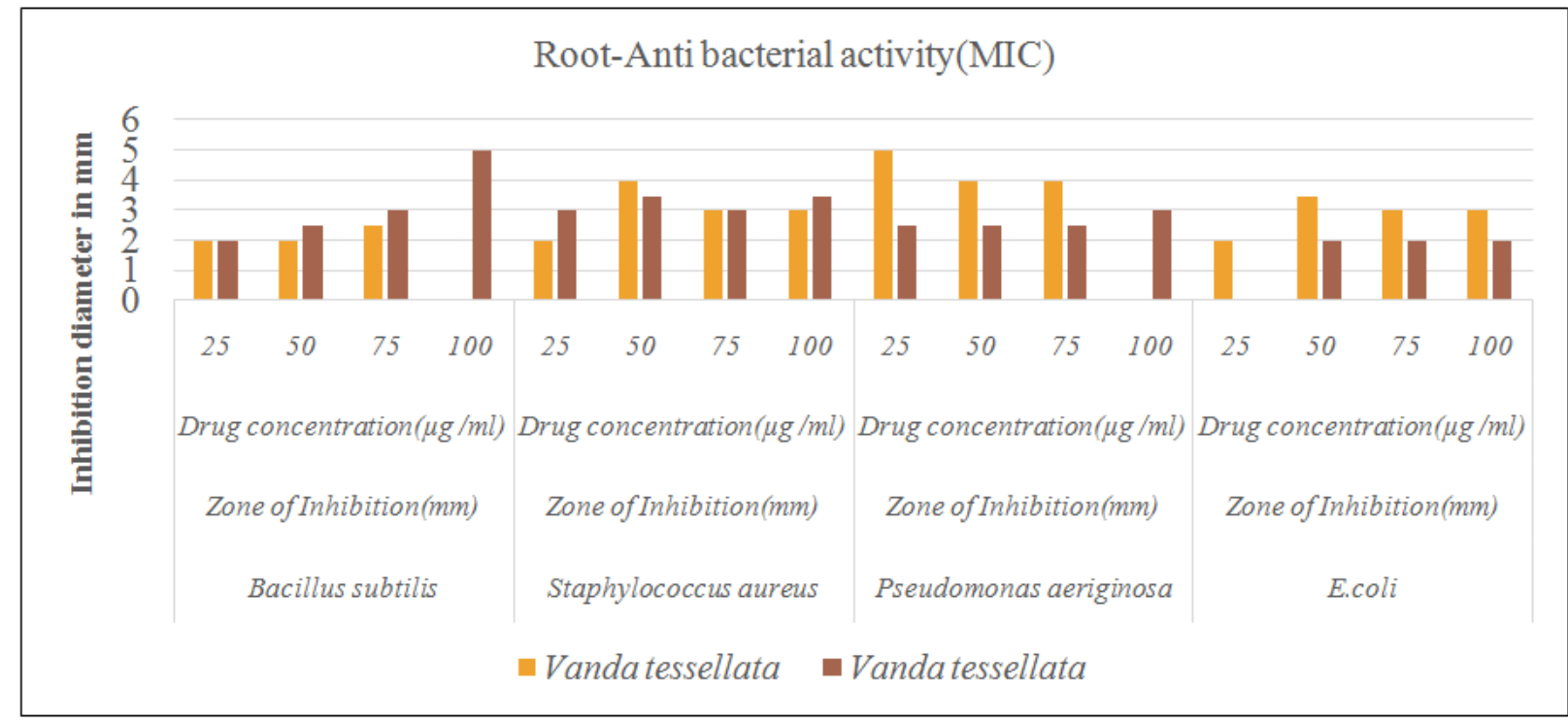

Plate 1:

Fig 3:-Antibacterial activity (MIC) comparative analysis of root extracts.

Methanol root extracts $(25,50,75$ and100 $\mu \mathrm{g} / \mathrm{ml}$ concentration $)$

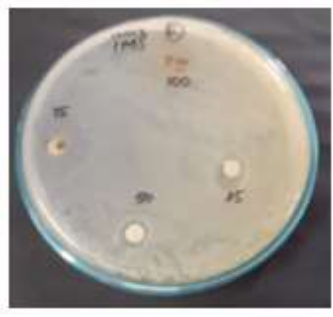

E. coli

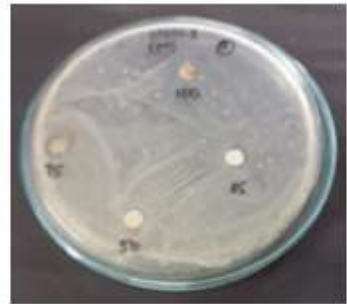

P. aeruginosa

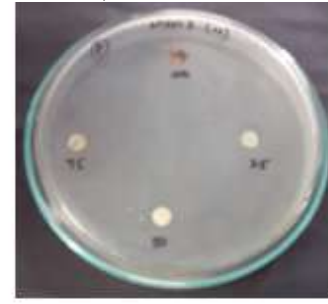

B. subtilis

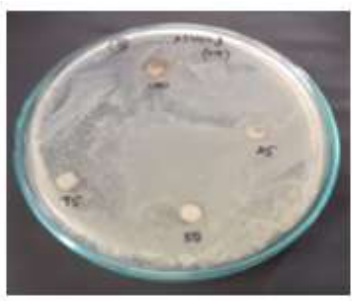

S. aureus 


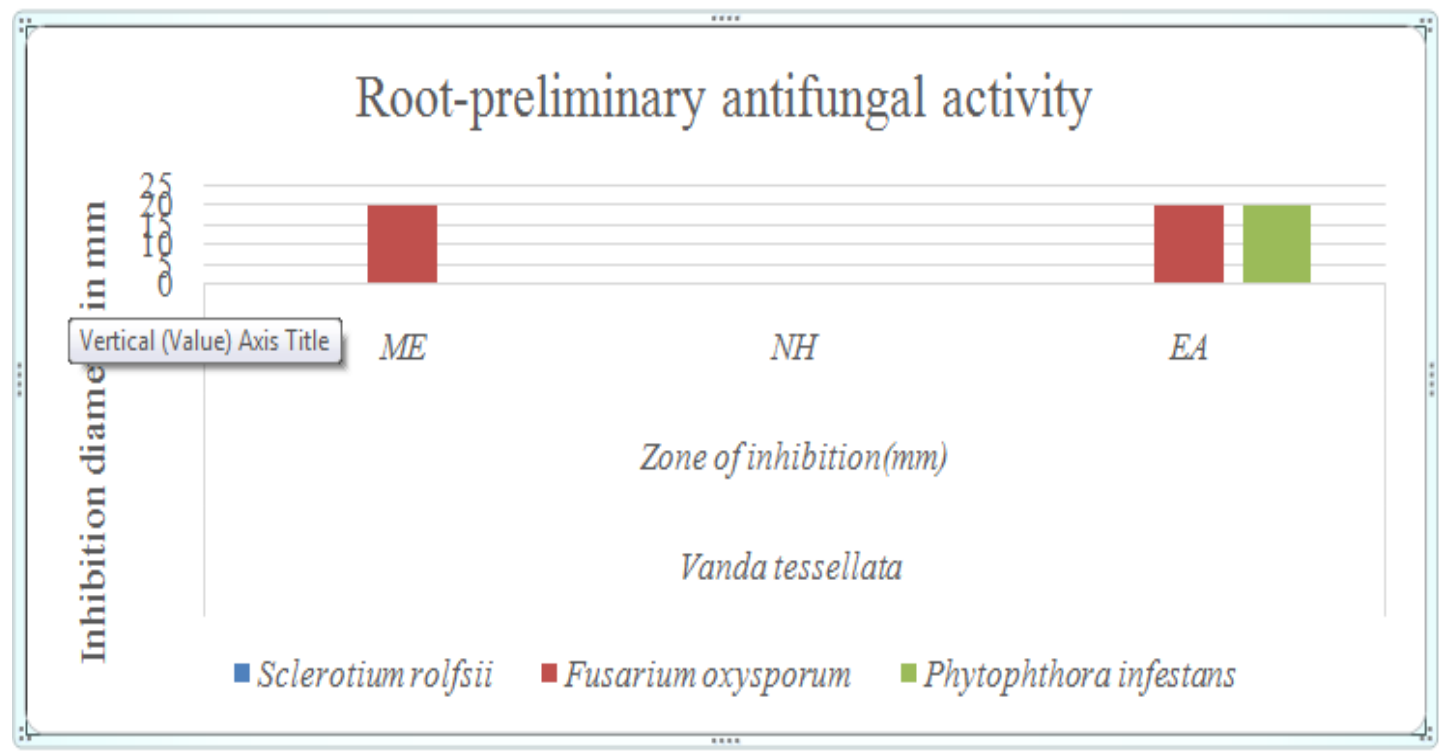

Fig 4:- Analysis of preliminary antifungal activity of different root extracts.

Ethyl acetate root extracts (25,50,75 and100 $\mu \mathrm{g} / \mathrm{ml}$ Concentration):

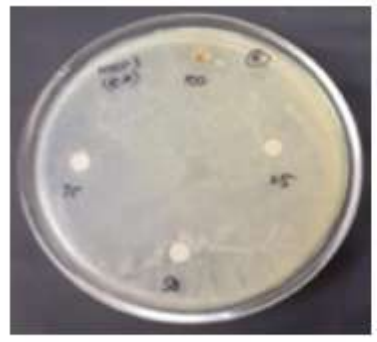

E. coli

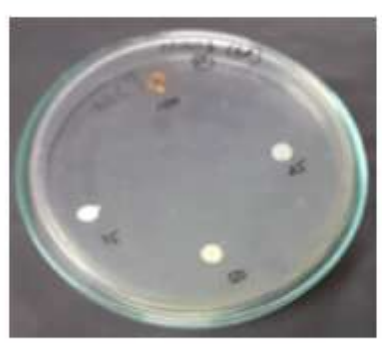

P. aeruginosa

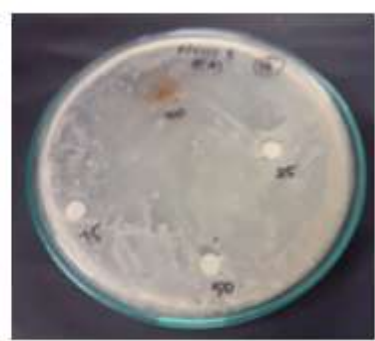

B. subtilis

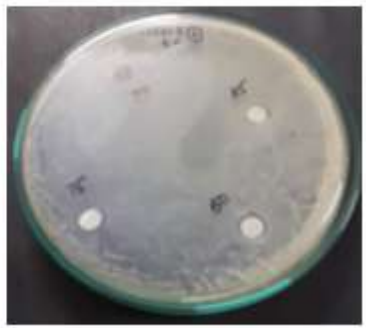

S. aureus

\section{Antifungal activity:}

Antifungal activity of different root extracts was conducted in two phases. Preliminary studies were carried out by disk diffusion method to find out the susceptibility of the selected fungal strains to each of the tested plant extracts. Based on the primary activity of the tested extracts on the fungal strains, minimum inhibitory concentration (MIC) of effective root extracts were employed to evaluate antifungal properties.

\section{Antifungal activity of root extracts:}

Root extracts of Vanda tessellata were tested for their antifungal activity against three fungal strains Viz Fusarium oxysporium, Sclerotium rolfsii and Phytophthora infestans by disk diffusion method using three different solvents viz., methanol, n-hexane and ethyl acetate.

Of all the extracts methanolic root extracts $V$. tessellata was the only one that exerted inhibition on the growth against $F$. oxysporum. (Table:4, Fig:4\&Plate-2)

Similarly, ethyl acetate root extracts of $V$. tessellata exerted an effect on the growth of $P$. infestans and $F$. oxysporium. None of the n-hexane extracts of roots of $V$. tessellata was effective inhibitors against the three fungal strains tested. (Table:4, Fig:4\&Plate-2)

Table 4:- Analysis of preliminary antifungal activity of different root extracts

$\mathrm{ME}=$ Methanolic extract, $\mathrm{NH}=\mathrm{N}-\mathrm{Hexane}$ extract, $\mathrm{EA}=$ Ethyl acetate extract $* *=$ No activity 


\begin{tabular}{|c|c|c|c|}
\hline & $\begin{array}{l}\text { Zone } \\
(\mathrm{mm})\end{array}$ & & \\
\hline & $\overline{\text { ME }}$ & NH & EA \\
\hline Sclerotium rolfsii & $* *$ & $* *$ & $* *$ \\
\hline Fusarium oxysporum & 20 & $* *$ & 20 \\
\hline Phytophthora infestans & *** & $* *$ & 20 \\
\hline
\end{tabular}

\begin{tabular}{|c|c|c|c|c|c|c|c|c|c|c|c|c|c|}
\hline \multirow{3}{*}{ 志 } & \multirow{3}{*}{$\frac{0}{0}$} & \multicolumn{4}{|c|}{ S.rolfisii } & \multicolumn{4}{|c|}{ F. oxysporum } & \multicolumn{4}{|c|}{ P. infestans } \\
\hline & & \multicolumn{4}{|c|}{ Zone of inhibition $(\mathrm{mm})$} & \multicolumn{4}{|c|}{ Zone of inhibition $(\mathrm{mm})$} & \multicolumn{4}{|c|}{ Zone of inhibition $(\mathrm{mm})$} \\
\hline & & 25 & 50 & 75 & 100 & 25 & 50 & 75 & 100 & 25 & 50 & 75 & 100 \\
\hline \multirow[t]{2}{*}{ V.tessellata } & $\mathrm{ME}$ & $* *$ & ** & ** & $20 \pm 0.028$ & $* *$ & $24 \pm 0.028$ & $22 \pm 0.028$ & $20 \pm 0.028$ & $* *$ & $* *$ & $18 \pm 0.57$ & $16 \pm 0.57$ \\
\hline & EA & $* *$ & $* *$ & $* *$ & $23 \pm 0.028$ & ** & $20 \pm 0.028$ & $19 \pm 0.57$ & $16 \pm 0.57$ & $* *$ & *** & $24 \pm 0.028$ & $22 \pm 0.028$ \\
\hline
\end{tabular}

Table 5:- Antifungal activity (MIC) comparative account of root extracts.

Minimum inhibitory concentrations (MIC's) of the effective root's extracts:

Minimum inhibitory concentrations (MIC's) of two effective root extracts were employed to evaluate for their antifungal activity

Concentrations $(\mu \mathrm{g} / \mathrm{ml})$ 25,50,75,100 ME=Methanolic extract; EA= Ethyl acetate extract; \pm standard mean error; ** =No activity.

Methanol root extracts of $V$. tessellata was most effective on S. rolfisii fungal growth retardation and $F$. oxysporum. (Table:5, Fig:5 \&Plate-2)

Results noted with ethyl acetate root extracts of $V$. tessellata against $F$. oxysporium and $P$. infestans were more or less to similar to their methanolic counterparts. (Table:5, Fig:5 \&Plate-2)

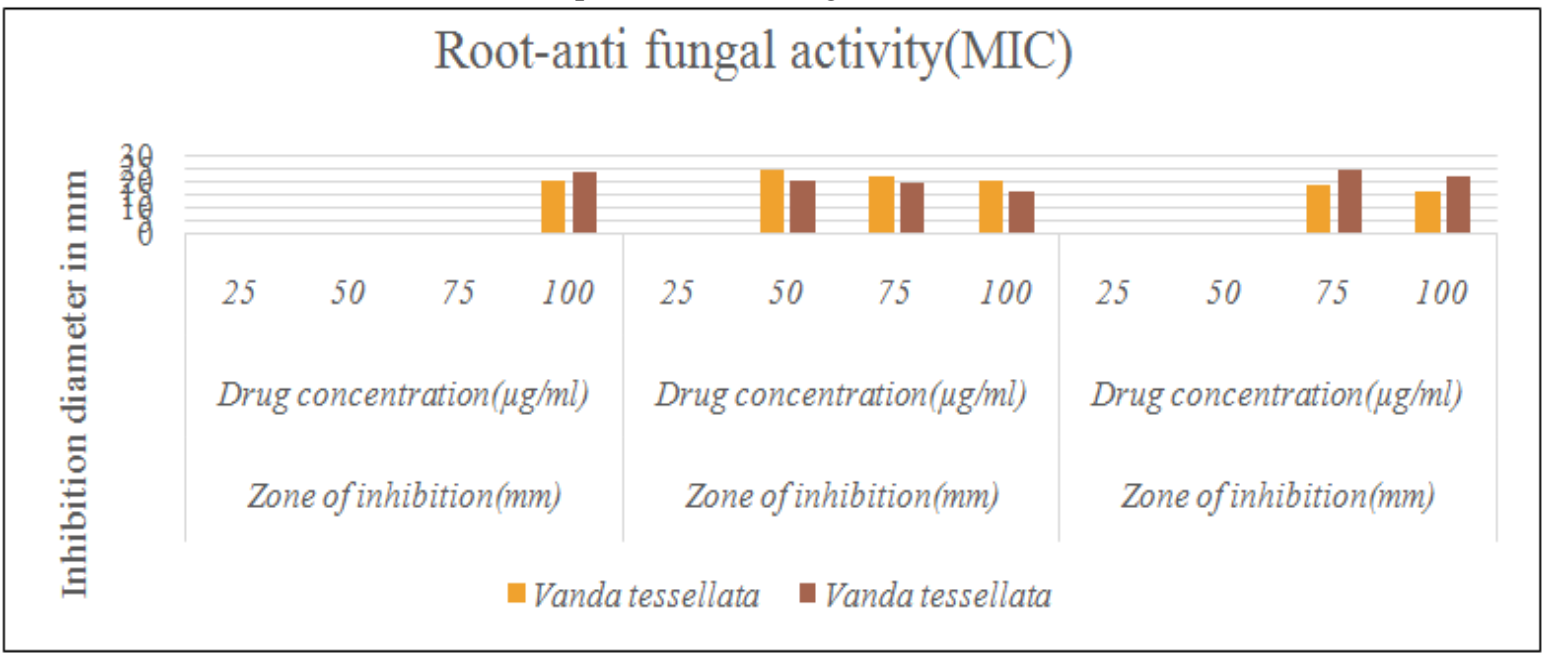

Fig 5:-Antifungal activity (MIC) comparative account of root extract.

Plate 2:

Methanol root extracts $(25,50,75,100 \mu \mathrm{g} / \mathrm{ml}$ concentration):

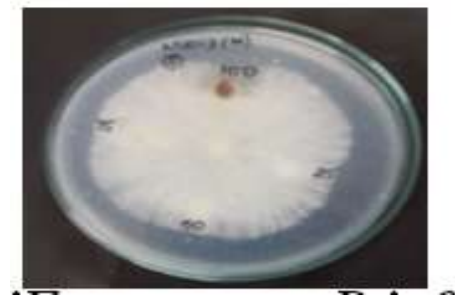

S. rolfisii

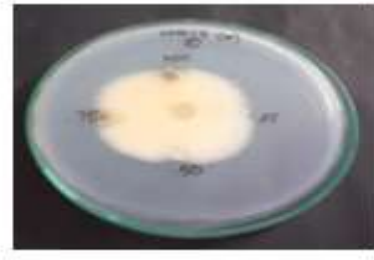

F. oxysporum

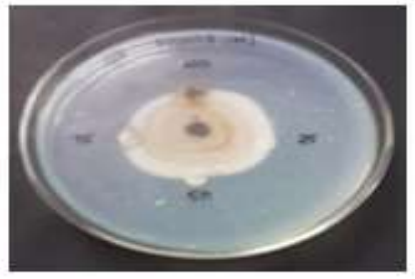

P. infestans 


\section{Ethyl acetate root extracts $(25,50,75,100 \mu \mathrm{g} / \mathrm{ml}$ concentration):}

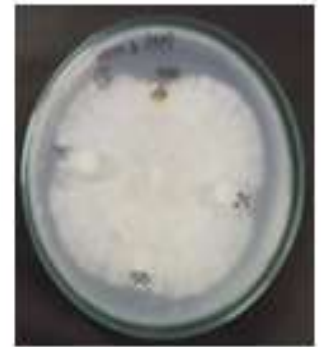

S. rolfisii

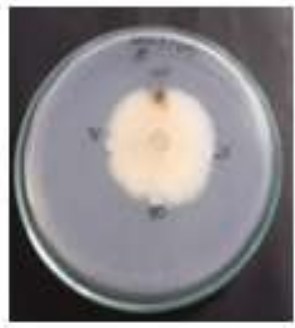

F. oxysporum

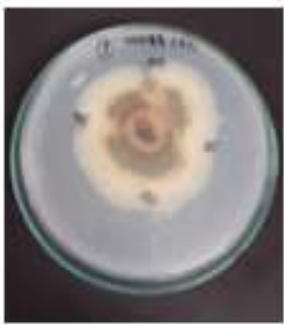

P. infestans

Anticancer activity:

In the present study, the anti-proliferative activity of root extracts of $V$. tessellata was carried out on two cell lines Viz Human hepatoma cell line Hep G2 and Murine skin Melanoma Cell line- B16-F10 by SRB assay (Sulforhodamine B colourimetric assay). SRB assay is a useful and highly sensitive technique for qualitative analysis of anticancer activity. As per the SRB assay protocol, $\mathrm{GI}_{\mathbf{5 0}}$, TGI, $\mathrm{LC}_{\mathbf{5 0}}$ values are calculated as stated by the National Cancer Institute. If percentage growth inhibition is $\geq 50$ at any of above concentration, then it is indicative of the effectiveness of the study drug. Adriamycin is used as a positive control.Triplicate experiments were performed, and the average values are calculated and tabulated in Table-6.

An in-vitro study of root extracts of $V$. tessellata exhibited little anti-proliferative activity on the Hep G2 and B16F10 cell lines. Based on the calculations from graphs, using GraphPad prism software, it is extrapolated that above $80 \mu \mathrm{g} / \mathrm{ml}$ concentration, of any of the extracts, is necessary to exert $50 \%$ growth inhibition of the two cell lines. (Table:6-7, Fig:6 \& Plate-3)

Table 6:-Anticancer activity comparative analysis of the root on two cancer cell lines

\begin{tabular}{|c|c|c|c|c|c|c|c|c|}
\hline \multirow[t]{3}{*}{ Plant name } & \multicolumn{4}{|l|}{ HEP-G2 } & \multicolumn{4}{|l|}{ B16-F10 } \\
\hline & \multicolumn{4}{|c|}{ Drug Concentration $(\mu \mathrm{g} / \mathrm{ml})$} & \multicolumn{4}{|c|}{ Drug Concentration $(\mu \mathrm{g} / \mathrm{ml})$} \\
\hline & 10 & 20 & 40 & 80 & 10 & 20 & 40 & 80 \\
\hline $\begin{array}{l}\text { Vanda } \\
\text { tessellata }\end{array}$ & $95.3 \pm 1.08$ & $95.4 \pm 1.06$ & $111.6 \pm 1.7$ & $145.9 \pm 8.3$ & $111.3 \pm 2.01$ & $121.6 \pm 1.65$ & $132.1 \pm 4.29$ & $125 \pm 3.11$ \\
\hline $\begin{array}{l}\text { Positive } \\
\text { control } \\
\text { compound } \\
\text { (ADR) }\end{array}$ & $-15.3 \pm 0.01$ & $-25.2 \pm 0.02$ & $-32.3 \pm 0.04$ & $-21.9 \pm 0.05$ & $-71.0 \pm 0.04$ & $-71.8 \pm 0.05$ & $-71.0 \pm 0.06$ & $-56.1 \pm 0.07$ \\
\hline
\end{tabular}

HEP G2: Human hepatoma cell line, B16-F10: Murine skin Melanoma cell line ADR=Adriamycin. $\pm=$ S.M. E

Table 7:- GI 50 values of root.

\begin{tabular}{|l|l|}
\hline \multirow{2}{*}{ Hep-G2\&B16-F10 } & \begin{tabular}{l} 
Drug concentrations $(\boldsymbol{\mu g} / \mathbf{m l})$ calculated from the \\
graph \\
\cline { 2 - 2 }
\end{tabular} \\
\hline GI50* \\
\hline Panda tessellata & $>80$ \\
\hline & $<10$ \\
\hline
\end{tabular}

GI50 $=$ concentration of drug causing $50 \%$ inhibition of cell growth.

$\mathrm{ADR}=$ Adriamycin. 


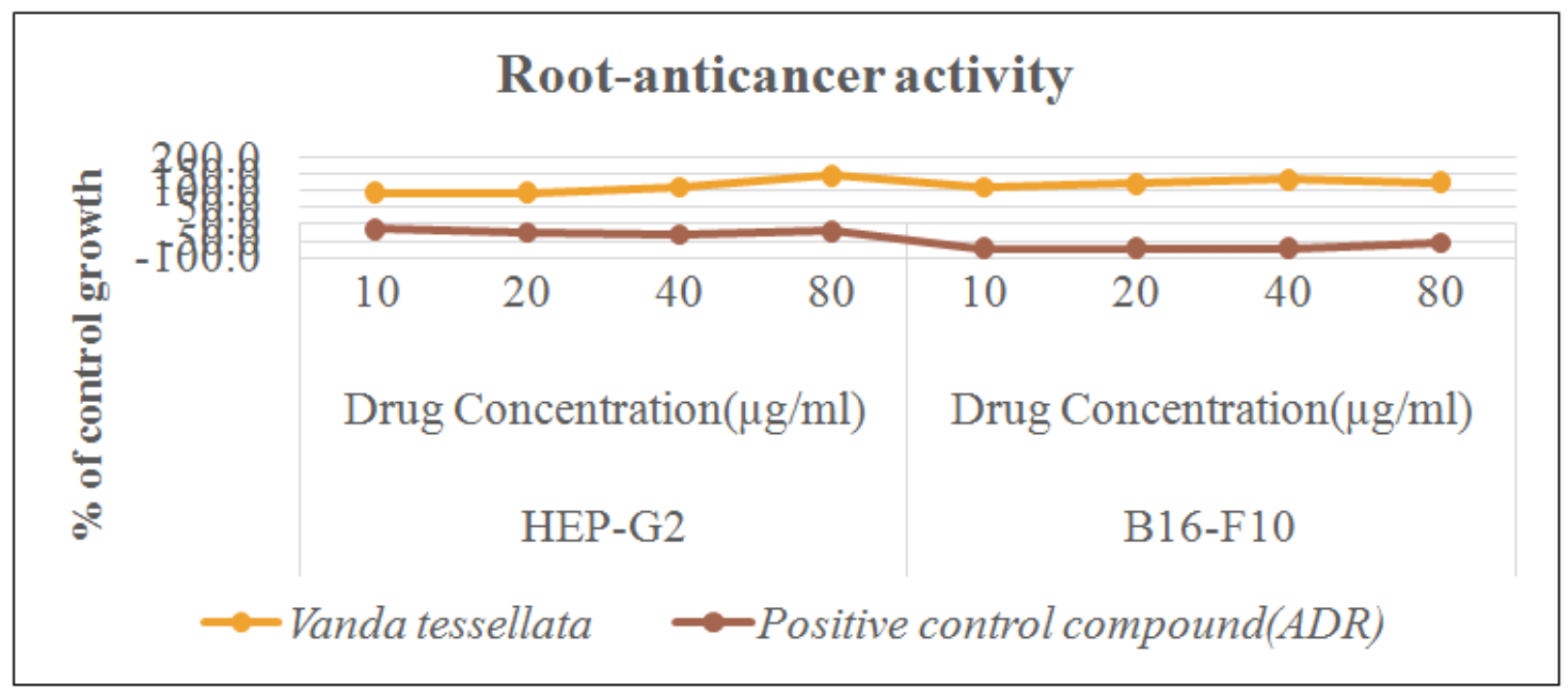

Fig 6:-Anticancer activity comparative analysis of the root on two cancer cell lines

\section{Plate 3:}

Anticancer activity at $80(\mu \mathrm{g} / \mathrm{ml})$ concentration:

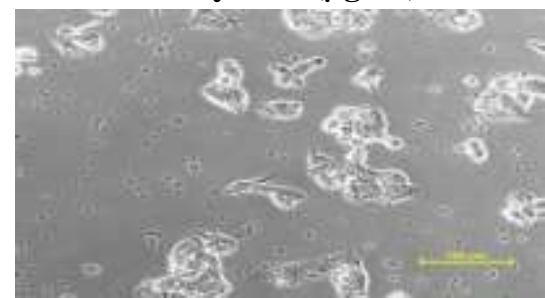

Hep-G2

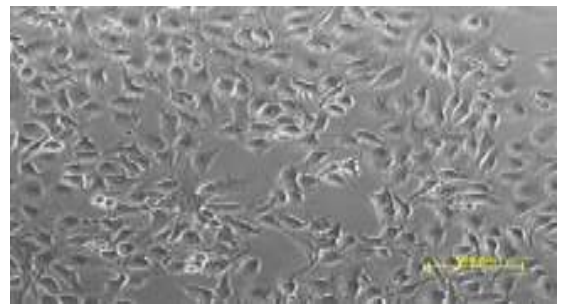

B16-F10

GC-MS (Gas Chromatography and Mass Spectroscopy analysis):

Gas chromatography-mass spectrometry (GC-MS), a key technological platform for secondary metabolite profiling in plant species, was carried out on root extracts of Vanda tessellata, using two solvents methanol and ethyl acetate. The total analysis of the extracts of samples revealed about 33 active compounds. Therapeutic values of the compounds are gathered from the PubChem, which is the database of chemical molecules which maintains three types of information namely, substance, compound and bioassays and the web link is https://pubchem.ncbi.nlm.nih.gov/. The list of compounds with their chemical names and therapeutic values are given in Table 8.

\section{GC-MSanalysis of plant extracts:}

A maximum number of compounds with antimicrobial property were found in ethyl acetate root extracts of $V$. tessellata. The methanolic root extract of $V$. tessellata, revealed four active compounds among which dimethyl ether is used in wart treatment. (Table:8, Fig:7) Whereas ethyl acetate root extract revealed thirty compounds in which 3Carboxymefenamic acid was the most noted compound with anti-inflammatory, analgesic, and antipyretic activities and joint disorders. Another compound, Norzimeldine, was known for antidepressant activity and the compound, 2(Trimethylsilyl) benzothiazoleis an anti-diabetic compound, Ferrocene, 1,2,3,4-tetrachloro was antimicrobial. The compound 5-Imidazolic acid, 2-[4-bromophenylazo] was known for antifungal activity and 4,6,8-Tetrathiatricyclo [3.3.1.13,7] decane with anticancer activity. The roots are popularly used in the treatment of cancer by tribals of the region. (Table:8, Fig:7). 


\section{Methanolic root extract:}

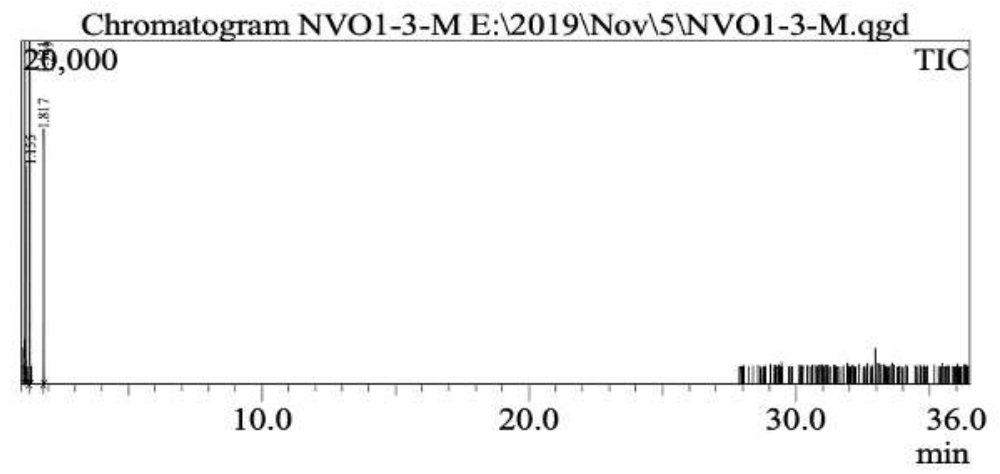

\section{Ethylacetate root extract:}

Chromatogram NVO-1-3-EA E:|2019 \NovlNVO-1-3-EA.qgd

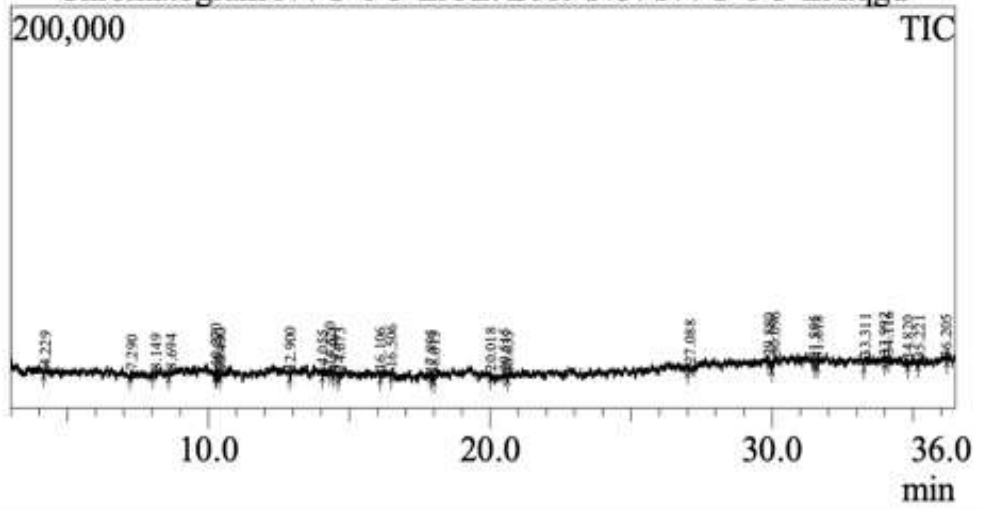

Fig 7:- Chromatograms

Table 8:- GC-MS profile:

Methanolic root extract:

\begin{tabular}{|l|l|l|}
\hline S.NO & Name of the compound & Therapeutic activity** \\
\hline 1 & Ethane, 1-chloro-1-fluoro- & Manufacture of ethylene \\
\hline 2 & Dimethyl ether & Wart treatment \\
\hline 3 & 4-Penten-2-one & Component of the fruit of Tamarindus indicus \\
\hline
\end{tabular}

Ethyl acetate root extract:

\begin{tabular}{|l|l|l|}
\hline S.NO & Name of the compound & Therapeutic activity** \\
\hline 1 & 2,4(1H,3H)-Pyrimidinedione, 6-chloro-5-nit & Anti-viral, antineoplastic \\
\hline 2 & Spiro [5. alpha. -androstane-3,2'-thiazolidine], & Anticancer \\
\hline 3 & 1-Pyrrolidinecarboxylic acid, 2-[[[5-[[(3-am & Unknown \\
\hline 4 & 5.alpha. -Androstan-12-one, cyclic ethylene & Antioxidant \\
\hline 5 & Norzimeldine & Anti-depressant \\
\hline 6 & 3-Carboxymefenamic acid & $\begin{array}{l}\text { Anti-inflammatory, analgesic, and } \\
\text { antipyretic activities. }\end{array}$ \\
\hline 7 & 2,7:3,6-Dimethanonaphth[2,3-b] oxirene, 3, & Anti-cancer \\
\hline
\end{tabular}




\begin{tabular}{|l|l|l|}
\hline 8 & Cyclohexanone, 2-[(4-bromophenyl)-1-pipe & Anti-tubercular \\
\hline 9 & Acetic acid, 8-acetoxy-6-benzenesulfonyl-2 & Anti-microbial \\
\hline 10 & Ethyl 2-(2-chloroacetamido)-2-[4-chloro-2- & Anti-inflammatory \\
\hline 11 & 5-(6-Butoxy-1-butylbenz[cd]indol-2(1H)-yl & Antihypertensive \\
\hline 12 & Thionaphthene, 2-[1-[1-piperidyl] cyclohexy & Anti-Parasitic \\
\hline 13 & 2,2-Dimethylpropane, 1,3-dioxybis (N, N-dii & Anti-microbial \\
\hline 14 & Ferrocene, 1,2,3,4-tetrachloro- & Antimicrobial, \\
\hline 15 & $3^{\prime}, 4^{\prime}, 5 ', 6$ '-Tetrabromobenzo[1',2'-b]-1,4-diaz & Enzyme inhibitor \\
\hline 16 & Dispiro[1,3-dioxolane-2,1'(4'H)-cyclobutadi & Anti-microbial \\
\hline 17 & D(15)-Norpregnan-20-ol, 20-methyl-, (5.alp & Unknown \\
\hline 18 & 2,4,6,8-Tetrathiatricyclo [3.3.1.13,7] decane, & Anti-cancer \\
\hline 19 & 5-Imidazolic acid, 2-[4-bromophenylazo]- & Anti-fungal \\
\hline 20 & Pregnan-20-one, 3,11,21-tris[(trimethylsilyl & Anti-bacterial \\
\hline 21 & $3-$-Methylindole-2-carboxylic acid, 4,5,6,7-t & Anti-depressant \\
\hline 22 & 3-Allyl-5-(3-ethyl-2(3H)-benzothiazolylide & Anti-cancer \\
\hline 23 & 2-[3-Chloro-4-methylphenyl]-2-[4-pyridinyl & Anti-hypersensitive \\
\hline 24 & Silane, trimethyl [5-methyl-2-(1-methylethyl & Antioxidant \\
\hline 25 & N-(3-Chlorophenyl)-2-hydroxyimino-aceta & Unknown \\
\hline 26 & 1-Methoxy-6-trimethylsilyloxyhexane & Antioxidant \\
\hline 27 & 4-Hydroxy-3-phenyl-4,6,6-trimethylhexahy & Anti-depressant \\
\hline 28 & 2-(Trimethylsilyl)benzothiazole & Antidiabetic \\
\hline 29 & - alpha. -D-Galactopyranose, 6-O-(trimethyls & $\begin{array}{l}\text { Inhibitors of phospholipase C isozymes } \\
\text { anti-cancer }\end{array}$ \\
\hline 30 & Arabinitol, pentaacetate & Cell immobilization \\
\hline
\end{tabular}

PubChem- Database of chemical molecules which maintains three types of information namely, substance, compound and bioassays.

\section{Discussion and Conclusions:-}

One of the key factors influencing the extraction efficiency of bioactive compounds from plant extracts is an extraction solvent. Besides, the concentration of the crude drug, temperature, plant parts used for the extraction of secondary metabolites and rate of diffusion are the other factors that influence the efficacy of the extract [23].

In the overall preliminary screening, ethyl acetate extracts showed more promising activity against tested bacteria compared to its methanolic counterparts [12].

None of the hexane extracts of the root had any inhibitory activity against the bacterial strains tested. Reduced ability of hexane to extract polar solutes could be the reason for non-performance of hexane extracts [30,31].

Bacteriostatic efficacy of $V$. tessellata against all the four bacterial strains as can be inferred from minimum inhibitory concentrations (MIC), was in accordance with the studies of earlier workers[1,4,5,10,12].Better performance of V.tessellata against the two gram-negative bacteria amply supports the earlier studies[4,5,26].

Orchids are known to contain a host of phytochemicals, including alkaloids, triterpenoids and phenolic compounds [13]. Phytochemical analysis of Vanda tessellata revealed several phytocompounds such as flavonoids, tannins, saponins, terpenoids, steroids and alkaloids [14,30].

Antibacterial and the antifungal activity of the root extracts was observed in the present study could be attributable to these metabolites like terpenoids, alkaloids phenolics in general and flavonoids in particular [18].

Absence of anticancer activity by the root extracts, in the present study, could be attributable to the solvent, DMSO, which might have failed to extract the bioactive chemicals that could mediate respective biological activity. Ascertaining the pharmacokinetics of an extract was difficult, if a compound, necessary for anti-prolific activity is insoluble in the solvent [7,31].

The absence of anti-prolific activity by the tested doses of V. tessellata was in line with studies of Chowdary et al., 2014 [9] where in LC 50 value with methanol extracts of $V$. tessellata was observed at $574.32 \mu \mathrm{g} / \mathrm{ml}$. Similarly, 
Shamsul Islam et al., 2016 [27] reported that the methanolic root extract of the V. tessellata induced LC50 value at a concentration of $25.19 \mathrm{mg} / \mathrm{ml}$ on Brine Shrimp nauplii.

Gas chromatography-mass spectrometry (GC-MS), analyses were done to find out the active principles in root extracts of $V$. tessellata in two different solvents. GC-MS analyses revealed a battery of different compounds, many of which are with multi-therapeutic properties.

Both methanolic and ethyl acetate root extract a total of 33 analytes are revealed. The data indicate that the ethyl acetate extracts performed better and are a more promising therapeutic agent. The extracts can be used in various pharmaceutical applications.

\section{References:-}

1. Ahmed F, Sayeed A, Islam A, Salam SA, Sadik G, Sattar MA, Khan GAM:2000: Antimicrobial activity of extracts and a glycoside from Vanda roxburghii Br.Pak J Biol Sci., 5: 189-191.

2. Akarsh S, Kekuda PTR, Ranitha MC, Vidya P, Monica, Firdos G. (2016). Inhibitory the activity of some plants against Colletotrichum capsiciand Fusarium oxysporum f. sp. zingiberi. Journal of Medicinal Plants Studies; 4(4):165-168.)95.).

3. Basu K., Das G.B., Bhattacharya S.K., Lal R. and Das P.K. (1971) Anti-inflammatory principles of Vanda roxburghii. Current Science, 40:86-87.

4. Behera D., Rath C.C., Tayung K. and Mohapatra U.B. (2013) Ethnomedicinal uses and antibacterial activity of two orchid species collected from SimilipalBiosphere Reserve Odisha, India. Journal of Agricultural Technology, 9(5):1269-1283.

5. Bhattacharjee B., Islam T., Rahman Z., and Islam S. M. S. (2015) Antimicrobial activity and phytochemical screening of whole plant extracts of Vanda tessellata (Roxb.) Hook. Ex. G. Don. World Journal of Pharmacy and Pharmaceutical Sciences, 4(1): 72-83.

6. Biswas K., Sinha S.N. (2020) Evaluation of Phytoconstituents and Antibacterial Activity of Vanda tessellata Using In Vitro Model. In: Khasim S., Hegde S., González-Arnao M., Thammasiri K. (eds) Orchid Biology: Recent Trends \&Challenges. Springer, Singapore

7. Chavan Rohit, Khan Mujahid, Sathe Ninad, Mankar Nitin (2016) A review SRB assay for screening anticancer activity of herbal drugs (in-vitro) IAMJ: ISSN:2320 5091 Volume 4; Issue 02; January 2016

8. Chopra R.N. (1956) Glossary of Indian medicinal plants. New Delhi. CSIR.

9. Chowdhury M.A., Rahman M.M., Chowdhury M.R., Uddin M.J., Sayeed M.A. and Hossain M.A. (2014) Antinociceptive and cytotoxic activities of anepiphytic medicinal orchid: Vanda tessellataRoxb. BMC Complementary and Alternative Medicine, 14:464

10. Das S., Bhattacharya A. and Bhattacharya A.K. (1967) Active constituents of Vanda roxburghiiR. Br. Journal of Indian Chemical Society 1967; 44: 804-5.

11. Gupta C. (2016) Isolation and characterization of new 17-ketosteroid as antimicrobial agent from Vanda tessellata (Roxb.) hook. World Journal of Pharmceutical Science, 4(4): 45-51.

12. Gupta C.H. and Katewa S.S. (2012) Antimicrobial testing of Vanda tessellateleaf extracts. Journal of Medicinal and Aromatic Plant Science, 34:158-62.

13. Gutierrez RMP. (2010) Orchids: A review of uses in traditional medicine, its phytochemistry and pharmacology. J Med Plants Res; 4(8):592-638.

14. Ghani A., Rastogi Ram., and Mehrota B. N. (1990-1994) Compendium of Indian Medicinal plants. Vol. V, CDRI Lucknow and National Institute of science and communication. 757.

15. Haroon Khan, Marya, TarunBelwal, Mohd Tariq, Atanas G. Atanasov, Hari Prasad Devkota, (2019) Genus Vanda: A review on traditional uses, bioactive chemical constituents and pharmacological activities, Journal of Ethnopharmacology,Volume 229, Pages 46-53,ISSN 0378-8741,https://doi.org/10.1016/j.jep.2018.09.031

16. J. F. Hindler and J. K. Jorgensen, (2007) “Antimicrobial susceptibility testing: procedures in antimicrobial susceptibility testing," in Textbook of Diagnostic Microbiology, C. R. Mahon, D. C. Lehman, and G. Manuselis, Eds., pp. 319-353, Saunders Elsevier, Beijing, China

17. Jonathan HK, Raju SAJ. (2005) Terrestrial and epiphytic orchids of Eastern Ghats. EPTRI - ENVIS Newsletter; 11(3): 2-4.

18. Mamta Saxena, Jyoti Saxena, Rajeev Nema, Dharmendra Singh and Abhishek Gupta. (2013) Phytochemistry of Medicinal Plants. Journal of Pharmacognosy and Phytochemistry. 2013; 1(6): 168-182. 
19. Magiatis, P., Skaltsounis, A.L., Chinou, I. and Haroutounian, S.A., 2002. Chemicalcomposition and in-vitro antimicrobial activity of the essential oils of three Greek Achillea species. ZeitschriftfürNaturforschung C, 57(3-4), pp.287-290.

20. MounyrBalouiri, Moulay Sadiki, Saad Koraichi Ibnsouda, (2016) Methods forinvitro evaluating antimicrobial activity: A review, Journal of Pharmaceutical Analysis, Volume 6, Issue 2, Pages 71-79, ISSN 20951779,https://doi.org/10.1016/j.jpha.2015.11.005

21. Mohammed Mozammel Hoque, Laila Khaleda, Mohammad Al-Forkan (2016) Evaluation of pharmaceutical properties on microbial activities of some important medicinal orchids of Bangladesh. Journal of Pharmacognosy and Phytochemistry 2016; 5(2): 265-269

22. Oregon State University (2012). GC-MS: How does it Work? Environmental HealthSciences Center Corvallis OR 97331 http://www.unsolvedmysteries.oregonstate.edu/MS_05

23. Prescott LM, Harley PJ, Klein AD. Microbiology. 7th ed. McGraw Hill Publisher, Singapore; 2008 , p.94-122.

24. Paul P, Chowdhury A, Nath D, Bhattacharjee MK. (2013): Antimicrobial efficacy Oforchid extracts as potential inhibitors of antibiotic-resistant strains of Escherichia coli. Asian J Pharm Clin Res; 6(3):108-111 Pal R.,

25. Rajendran A, Rao RN, Kumar RK, Henry AN. (1997) Some medicinal orchids of Southern India. Ancient Science of Life; 17(1):10-14

26. Ranjitha MC, Akarsh S, Kekuda PTR, Darshini SM, Vidya P.2016 Antibacterial activity of some plants of Karnataka, India. J PharmacognPhytochem; 5(4):95-99.)

27. Shamsul Islam S.M., Sayeed H., Abrar Shahriyar S.K., Ferdous A. and Islam A. (2016) Antioxidant, Analgesic and Cytotoxic Activity of Methanolic Extract of Vanda Roxburghii Root. International Journal of Pharmaceutical ScicencesResearch, 7(7): 2944-50.doi: 10.13040/IJPSR.0975-8232.7(7).2944-50

28. Skoog DA, Holler FJ, Crouch SR (2007). Principles of Instrumental Analysis. 6th Edition. Brooks/Cole Cengage Learning, Chapters 11, 20, 26, 27.

29. SyedZameer Hussain* and Khushnuma Maqbool (2014) GC-MS: Principle, Techniqueand its application in Food Science Division of Post-Harvest Technology, Sher-e-Kashmir University of Agricultural Science and Technology of Kashmir Kashmir, India *Address for correspondence: zameerskuastj@rediffmail.comINT J CURR SCI 2014, 13: E 116-126.

30. Sirisha J.V., Sailakshmi K. and Vijayal K. (2013) Human red blood cell (HRBC) membrane stabilizing activity of leaves of pet-ether extract of Vanda tessellataRoxb. International Ayurvedic Medicinal Journal, 1:5-8.

31. Thanh Van Ngo, Christopher James Scarlett, Michael Christian Bowyer, Phuong DucNgo, and Quan Van Vuong (2017), Impact of Different Extraction Solvents ofBioactive Compounds and Antioxidant Capacity from the Root of SalaciachinensisL.Volume 1, pp 1-8

32. T J Siek. (1978). Effective use of organic solvents to remove drugs from biological specimens. Clin Toxicol.;13(2): 205-30.doi: 0.3109/15563657808988234

33. M. J., Rahman M. M., Abdullah-Al-Mamun M. and Sadik G. (2015) Vanda roxburghii: an experimental evaluation of antinociceptive properties of a traditional epiphytic medicinal orchid in animal models. BMC complementary and alternative medicine, 15(1): 1 .

34. VanichaVichai and Kanyawim Kirtikara. (2006) Sulforhodamine B colorimetric assay for cytotoxicity screening Nature Protocols 1: 1112- 1116,

35. Yadav NP and Dixit VK (2003) Recent approaches in herbal drug Standardization. 